\title{
Empirical Study on Economic Analysis of Construction of Green Prefabricated Concrete Structure System
}

\author{
Liao Liping ${ }^{1, *}$ \\ ${ }^{1}$ Jiangxi Institute of Economic Administrators, 330088 Jiangxi Nanchang, China
}

\begin{abstract}
At present, the socialist economy with Chinese characteristics continues to develop and the process of urbanization is rapidly advancing. The construction industry plays an important role in the development of the national economy and the process of urbanization. However, the traditional construction industry has high energy consumption and large pollution, which has brought huge pressure on the ecological environment and is not conducive to the sustainable development of the industry. The transformation and upgrading of the construction industry are an inevitable trend in the development of the industry. Prefabricated building, as a new structure, is a typical green building. This article introduces the development status of prefabricated buildings, and analyzes the influencing factors of their construction costs. The article uses survey method, literature research method, comparative research method, and empirical research method to introduce the development status of prefabricated buildings, and analyzes the factors affecting its construction costs, and concludes that national policies, technologies, and management affect prefabricated building costs.Based on this, we propose countermeasures and suggestions: strengthen macro-control, improve laws and regulations and standards; focus on training professional and technical personnel, improve the level of industry production management; scientific arrangement, strengthen management, improve industrial operations, and conduct empirical analysis.
\end{abstract}

\section{Introduction}

In January 2013, the National Development and Reform Commission and the Ministry of Housing and Construction jointly issued the "Green Building Action Plan", which pointed out the direction for the development of prefabricated buildings. In June 2016, the "Guiding Opinions on Vigorously Developing Prefabricated Buildings" was issued to encourage vigorous development of prefabricated buildings. In March 2017, the Ministry of Housing and Urban-Rural Development issued the "Thirteenth Five-Year Plan" Prefabricated Building Behavior Plan, which called for a comprehensive and active promotion of the development of prefabricated buildings and clear construction goals by 2020. At the same time, various provinces, cities, and regions have also issued relevant policies and measures for the development of prefabricated construction industry, comprehensively coordinated and coordinated development of the entire industrial chain of feasibility research, decision-making, survey, design, production, construction and installation of prefabricated buildings. Improve the development momentum and supporting capabilities of the local fabricated building industry[1]. As the development focus of construction industrialization, industrialization and informationization, China's fabricated building market will usher in unprecedented development opportunities.
As a new industrial model, the standardized design and factory production of prefabricated buildings greatly reduce the amount of on-site pouring work and improve the efficiency of project construction. At the same time, compared to the traditional cast-in-place building with a long cycle, open-air operations, and high-altitude operations, prefabricated buildings reduce tedious on-site practices and use a large number of mechanized operations, greatly improving construction safety. In addition, the centralized processing of prefabricated buildings reduces the amount of dust and construction noise; the energy consumption is greatly reduced, which is conducive to the industry's green and sustainable development[2]. It can be said that fully understanding the advantages of prefabricated buildings, removing various obstacles in their development, and actively promoting them are an important issue in the construction industry at present and for a period of time.

\section{Development status of prefabricated buildings}

\subsection{Government attaches great importance, but policy support is not accurate enough}

Since 2013, relevant departments from the central government to the local government, from the Ministry of Housing and Construction to the National

\footnotetext{
* Corresponding author: Liao Liping; email: zjsping2008@163.com
} 
Development and Reform Commission have intensively introduced some guidelines and policies to encourage and support the development of prefabricated buildings. These policies cover land use support, financial subsidies, floor area ratio, special support, tax and fee reduction, performance appraisal, loan tilt, green approval, and consumption orientation. Especially in terms of tax and fee policies, the support is unprecedented. At the same time, many factors such as land approval and plot ratio have also benefited many industry enterprise groups. However, compared to the traditional cast-in-situ concrete structure, the prefabricated building structure system has its inherent production characteristics. At the early stage of its development, it had a significant investment amount, high production and processing costs, low overall return rate, and long construction period Features. In contrast to these characteristics, the top-level design of the government system is obviously insufficient and imperfect. There are disadvantages such as lack of pertinence, accuracy, and effectiveness. These factors have largely restricted the rapid development of the fabricated building industry. In order to stimulate the internal driving force of the industry's development, and to support the subjective initiative of each subject to the utmost, the government must also implement precise policies and perseverance to provide institutional guarantee for the development of prefabricated buildings[3].

\subsection{Obvious advantages, but low overall industry awareness}

As we all know, prefabricated building, originated from abroad, has many advantages that traditional cast-in-situ structure does not have. A large number of prefabricated components are used in prefabricated buildings, and the prefabricated components are completed in batches in the prefabrication factory, which reduces the amount of wood and steel formwork on the site, effectively saves resources and ensures quality. At the same time, the prefabricated building adopts the factory prefabricated and on-site lifting operation mode, which greatly shortens the construction period and improves the investment benefit. In addition, its unique construction organization process has fewer wet operations on site, reducing environmental pollution. However, the industry is affected by factors such as traditional thinking, and the industry's overall awareness is low. Assembled component production bases in various places have just emerged, or production investment is insufficient[4]. Even with the strong support and publicity of the government, industry companies' cognition of their assembly parts and prefabricated products is still relatively vague; they lack confidence in their development; they have a clear wait-and-see attitude, and the construction industry's awareness needs to be further improved.

\subsection{The market is gradually formed, but the technical standard system is incomplete}

According to incomplete statistics, as of the end of 2018, China's prefabricated building area has greatly increased, from 73.6 million square meters in 2015 to 293 million square meters in 2018 , accounting for $13.93 \%$ of the newly started area and achieving a composite of nearly $60 \%$. From a regional perspective, East China has developed the fastest, with Shanghai, Zhejiang, and Jiangsu as its typical representatives. Its prefabricated building areas accounted for $70 \%, 45 \%$, and $15 \%$ of the newly started area, respectively. From the perspective of enterprises, large state-owned construction enterprises are the main players in the market, accounting for more than $70 \%$ of the total market. They are mainly general construction contracting enterprises. China Construction, Shanghai Construction Engineering, Shanghai Urban Construction, and Beijing Housing Industrialization Group are the market leaders and representatives of the biggest beneficiaries. From the perspective of the types of prefabricated buildings, there are mainly three types: prefabricated wooden structures, prefabricated concrete structures (PC structures for short) and prefabricated steel structures. It can be said that the country's prefabricated construction market is gradually taking shape and its scale is expanding[5]. However, as a new structural system, prefabricated building design, factory production and processing, on-site construction and installation, test and inspection, acceptance, and post-maintenance all have their fixed characteristics. The corresponding supporting technical standards and specification systems are still not comprehensive. Without a system, it is difficult to support the development of prefabricated buildings for a period of time, which will inevitably affect the growth of its market size.

\section{Analysis of influencing factors of prefabricated building cost}

After investigation and analysis, the promotion of prefabricated buildings has encountered many obstacles, among which cost is one of the important influencing factors. The costs of component production and production, transportation costs of finished products, and on-site assembly and connection constitute the assembly building cost. It is a dynamic forming process, and its composition includes a series of costs incurred during the entire process, such as PC structure design costs, prefabricated production costs, component transportation costs, machinery lifting costs, on-site assembly costs, and subsequent maintenance costs[6].

\subsection{Country: policy, norms, standards system}

As an important way to develop green buildings, in the context of the country's push for ecological civilization, prefabricated buildings ushered in huge development opportunities. However, the current tax policy has brought challenges to prefabricated prefabricated buildings. For finished products such as prefabricated 
prefabricated components, $17 \%$ value-added tax (plus the difficulty of collecting all kinds of original data) compared to traditional cast-in-place structures. The tax rate of $\%$ has greatly increased the cost of building products, forcing few companies to adopt or even change design schemes, and abandon the use of assembly components.

At the same time, there is a lack of a unified system of norms and standards at the national level, and different provinces, cities, and local practices vary. A lack of proper safety and quality supervision system in the process of prefabricated building design, construction of prefabricated production, delivery from factory, lifting and splicing, and maintenance. In the context of this policy and norms, the safety of the main players in each market, the difficulty of quality control, and the cost have increased dramatically; moreover, various liability disputes are prone to occur. Without a complete and sound safety and quality assurance system and liability recovery system, the safety and quality of prefabricated buildings cannot be guaranteed, and costs are difficult to control[7].

\subsection{Technology: design, production, transportation, installation}

The cost of prefabricated buildings cannot be separated from design, production, transportation and installation. In terms of design, the main factors affecting the cost of prefabricated buildings include overall assembly rate and prefabrication rate. In the design process, the more complicated the building form, the more the component specifications and types involved. As a result, the construction and installation are more difficult, the more manpower, material resources and financial resources are required, and the cost is obviously increased. At the same time, the design link should take into account the use of molds as much as possible, reduce varieties, improve turnover, and avoid excessive sales costs[8]. Full consideration should be given to the same component type to increase the reuse rate of standard components and maximize the overall benefits.

In production, professional flow construction should be adopted to the maximum extent; when it conditions permit, make full use of the unit method operation. At present, the production process of prefabricated components is not highly mechanized, and it still mainly stays at the level of manual operation. The degree of standardization is not high, and the manual operation error is too large, which is also the reason for its high cost. At the same time, in the transportation process, the single mode, poor channels, and the overlength, oversize, and overweight of some components also restrict the cost of prefabricated buildings. In the process of construction and installation, the overall technical level of operators is low, and the degree of intelligent control is not high. The degree of mechanized construction is limited. The use of some large and special machinery is low. The cost is high, and the use and maintenance costs increase. In addition, the technical processing between various links and various types of work is not smooth, no technical system is formed, and safety and quality cannot be guaranteed. This also increases the safety cost and quality cost of prefabricated buildings.

\subsection{Management: Industry chain collaboration}

The construction process of prefabricated buildings is an organic whole, including component design, prefabricated production, transportation, hoisting, installation and maintenance, etc. There are many upstream and downstream industries and they are closely related. From a management perspective, the key to reducing the cost of prefabricated construction is how to ensure the synchronization and coordination of the upstream and downstream industries in various procedures and links. At present, there is a serious shortage of specialized and industrialized assembled professional and technical personnel. There is no dedicated construction operation team and related professional management personnel. Most of the management methods and management methods remain in the traditional traditional cast-in-situ building management mode. The technical isolation, fragmentation of management, and even conflicts between the design, prefabricated production, transportation, and on-site installation of PC components have led to serious resource waste and greatly increased management costs. At the same time, there are many component manufacturers at present, but the standards are inconsistent, and the levels are quite different, which leads to the overall low quality of components and accessories, which lacks the necessary supporting compatibility. A lack of a complete industrial chain that runs through the entire process of research and development, survey and design, processing and manufacturing, hoisting and transportation, construction and installation, protection and maintenance, and cannot truly realize the entire process, dynamic and multi-dimensional assembly cost control system.

At the same time, the connection between different types of work, different construction machinery, and different spreaders and the ability to collaborate also affect the cost of prefabricated buildings. Assembled building components are complex and diverse, involving different types of work and machinery. Limited by the traditional production model and the existing interest chain, the overall coordination of component research and development, prefabricated production, transportation and installation is poor, and safety, schedule and quality cannot be guaranteed, which also affects the cost of prefabricated construction to a certain extent.

\section{Measures to reduce the cost of prefabricated buildings}

\author{
4.1Strengthen macro-control and improve laws, \\ regulations and standards
}


Uniform industry norms have been promulgated nationwide; under the guidance of unified national regulations, provinces, cities and regions, combined with their own specific situations and specific problems, they have formulated a standard system and implementation rules that are in line with the development of local fabricated buildings. Establish a multi-level and multi-structured macro standard system for prefabricated buildings, especially in terms of finance and taxation, adjust tax rates appropriately for prefabricated components and other products, and give corresponding preferential policies; and provide active financial support to promote industry development. Standardize the business activities of PC component manufacturing enterprises, formulate uniform component production and acceptance standards; achieve standardized and large-scale production of PC components, improve labor productivity, and effectively reduce the cost of fabricated building structures[9].

Establish and improve the quality supervision system for the design, production, processing, lifting and transportation, and installation of prefabricated components. Strengthen safety and quality awareness, reduce safety and quality accidents, and reduce costs. Clarify the responsibilities of each participant, establish a system of full compensation for accountability, and reduce economic losses in all aspects.

\subsection{Efforts to train professional and technical personnel and improve the level of industry production management}

Talent is a key factor in the development of prefabricated buildings. Make full use of the rich theoretical resource advantages of local colleges and universities, the practical skill resource advantages of large state-owned leading enterprises, and the policy resource advantages of government construction administrative departments and training institutions, innovate institutional mechanisms, actively explore, and vigorously cultivate assembly-type expertise Talent. Through various forms such as order training, school-enterprise cooperation, and government-enterprise coordination, the curriculum system was optimized and the talent training mode with professional industry characteristics was reconstructed. Strengthen the training of composite talents in the industry, and strive to create a large number of application-oriented talents who not only understand the $\mathrm{R} \& \mathrm{D}$, design, construction, production, processing, transportation, installation and construction of prefabricated buildings, but also coordinate the management of industry and enterprises. Strengthen training and guidance, professional publicity, make full use of various platforms and media, vigorously publicize the relevant knowledge of prefabricated buildings, and improve the professional social recognition of the industry[10]. We will provide comprehensive training and special training for assembly construction workers in batches and channels, so as to combine theoretical learning with practical skills, effectively improve the technical and management level of employees, and give play to the key role of talents in reducing costs.

\subsection{Scientific arrangement, strengthening management, and improving industrial operations}

At present, most of the assembly-type production bases in various regions are scattered and operating separately, failing to form economies of scale. Scientific planning is needed to rationally arrange each component manufacturing enterprise, fully consider factors such as market size, transportation costs, technical exchanges, and cooperation to maximize the overall effect. Improve the current operating conditions of enterprises with decentralized product research and development, survey and design, production and processing, lifting and transportation, construction and installation, and build a new enterprise group management model that integrates the entire process, all elements, dynamic research, production, installation and management of prefabricated construction enterprises Organic enterprise industrial chain. Innovate the business management system of the enterprise, and fundamentally solve the core problem of multiple accruals of profit and tax on assembled components; strengthen the collaborative management of various types of work and enterprises, effectively reduce operating costs, and improve overall efficiency.

\section{Case study}

\subsection{Project Overview}

Combined with the actual situation of the project and considering the research situation of the project, we selected a project that can fully reflect the characteristics of the assembled project, the construction process and the consumption of human resources and machines. program. The project has 22 floors and a building area of $10121 \mathrm{~m}^{2}$. It is an assembled reinforced concrete structure. The vertical force adopts cast-in-place reinforced concrete structure, and the remaining beams, slabs and walls adopt assembled reinforced concrete structure. At the same time, a traditional frame-shear wall structure building was selected as a residential building with 19 floors and an area of 13,500 square meters. The basic characteristics of the two are shown in Table 1:

Table 1. Engineering project characteristics

\begin{tabular}{|c|c|c|}
\hline Engineering features & Traditional frame-shear structure & New assembled structure \\
\hline Floors & 19 & 22 \\
\hline Floor height $(\mathrm{m})$ & 2.8 & 2.8 \\
\hline Cornice height $(\mathrm{m})$ & 54.83 & 67.2 \\
\hline Building area $\left(\mathrm{m}^{2}\right)$ & 13500 & 10121 \\
\hline Type & Two elevators and four households & Two elevators and four households \\
\hline
\end{tabular}


The above projects are all in Nanchang City, which has a large similarity in terms of engineering characteristics and small regional errors, which is conducive to the subject research.

\subsection{Comparative analysis of individual indicators}

Analyze prefabricated buildings and traditional cast-in-situ buildings, compare their individual indicators, and look for differences. The selected comparison indicators are: brickwork project, steel bar project, concrete structure, plastering project, formwork project, exterior wall painting project, etc. The single index is the consumption index of various resources in the case of unit building area. According to the drawings and construction site, the following data are calculated. The results are shown in Table 2.

Table 2. Comparison of consumption of individual indicators

\begin{tabular}{|c|c|c|c|c|}
\hline Number & Division name & Traditional building & $\begin{array}{l}\text { Prefabricated } \\
\text { building }\end{array}$ & Measurement unit \\
\hline 1 & Brickwork & 0.15 & 0.04 & $\mathrm{~m}^{3} / \mathrm{m}^{2}$ \\
\hline 2 & $\begin{array}{l}\text { Reinforcement } \\
\text { engineering }\end{array}$ & 41.62 & 47.31 & $\mathrm{~kg} / \mathrm{m}^{2}$ \\
\hline \multirow[b]{2}{*}{ Among } & $\begin{array}{l}\text { PC component } \\
\text { reinforcement }\end{array}$ & \multirow[b]{2}{*}{41.62} & 22.51 & $\mathrm{~kg} / \mathrm{m}^{2}$ \\
\hline & $\begin{array}{c}\text { einforcement of } \\
\text { cast-in-situ } \\
\text { members } \\
\end{array}$ & & 24.80 & $\mathrm{~kg} / \mathrm{m}^{2}$ \\
\hline 3 & Concrete index & 0.38 & 0.41 & $\mathrm{~m}^{3} / \mathrm{m}^{2}$ \\
\hline \multirow[b]{2}{*}{ Among } & $\begin{array}{c}\text { PC component } \\
\text { concrete }\end{array}$ & \multirow[b]{2}{*}{0.38} & 0.2 & $\mathrm{~m}^{3} / \mathrm{m}^{2}$ \\
\hline & $\begin{array}{c}\text { Concrete for } \\
\text { cast-in-place } \\
\text { members }\end{array}$ & & 0.21 & $\mathrm{~m}^{3} / \mathrm{m}^{2}$ \\
\hline 4 & Plastering project & 2.78 & 0.38 & $\mathrm{~m}^{3} / \mathrm{m}^{2}$ \\
\hline 5 & Formwork project & 3.42 & 1.08 & $\mathrm{~m}^{3} / \mathrm{m}^{2}$ \\
\hline
\end{tabular}

\subsection{Comparison of Cost Indicators between Prefabricated Buildings and Traditional Building Engineering}

Based on the analysis in Table 3, it is not difficult to find that the unit concrete consumption and unit steel reinforcement usage of the prefabricated building structure system are slightly higher than those of the traditional cast-in-situ structure. In addition, other indicators are significantly lower than those of the traditional building. According to related quotas and cost indicators, two different types of cost data are calculated. According to the cost of building structure engineering, installation engineering cost, decoration engineering cost, etc., the differences between the two types of structure are found out[11].

First: the cost of the building structure. The cost data of prefabricated buildings and traditional cast-in-situ buildings are shown in Table 3.

Table 3. Cost analysis of construction projects

\begin{tabular}{|c|c|c|c|c|c|}
\hline Number & Project & $\begin{array}{c}\text { Traditional } \\
\text { building }\end{array}$ & $\begin{array}{c}\text { Prefabricated } \\
\text { building }\end{array}$ & Unit & Difference \\
\hline 1 & $\begin{array}{c}\text { Building } \\
\text { structure part }\end{array}$ & 1208.36 & 1531.9 & yuan $/ \mathrm{m}^{2}$ & -323.54 \\
\hline 2 & $\begin{array}{c}\text { Prefabricated } \\
\text { part }\end{array}$ & 1208.36 & 820.6 & yuan $/ \mathrm{m}^{2}$ & $/$ \\
\hline & $\begin{array}{c}\text { Construction } \\
\text { site part }\end{array}$ & & 711.3 & yuan $/ \mathrm{m}^{2}$ & $/$ \\
\hline
\end{tabular}

By comparison, it can be found that the building structure includes masonry, steel bars, formwork, roofing, plastering and so on. Compared with traditional cast-in-situ buildings, the unilateral cost of prefabricated buildings increased by $26.78 \%$. The reasons include the following: (1) Prefabricated buildings are in their infancy, and the scope of use is small, and there is no scale effect; (2) Prefabricated buildings lack professional operators, immature construction technology and high labor costs;
The specifications are higher, the requirements are stricter, and the consumption of various resources is greater.

Second: the cost of decoration works. In terms of decoration engineering, the cost of the two types of construction projects is quite different. The cost of traditional cast-in-situ building projects is 316.46 yuan / $\mathrm{m}^{2}$, while the cost of prefabricated building decoration projects is 265.31 yuan $/ \mathrm{m}^{2}$, saving 51.15 yuan $/ \mathrm{m}^{2}$. See Table 4 for details. 
Table 4. Cost Analysis of Decoration Engineering

\begin{tabular}{|c|c|c|c|c|c|}
\hline Number & Project & $\begin{array}{c}\text { Traditional } \\
\text { building }\end{array}$ & $\begin{array}{c}\text { Prefabricated } \\
\text { building }\end{array}$ & Unit & Difference \\
\hline 1 & $\begin{array}{c}\text { Prefabricated } \\
\text { part }\end{array}$ & 316.46 & 265.31 & yuan $/ \mathrm{m}^{2}$ & 51.15 \\
\hline 2 & $\begin{array}{c}\text { Decoration and } \\
\text { construction } \\
\text { costs } \\
\text { Decoration and } \\
\text { construction } \\
\text { costs }\end{array}$ & 316.46 & 265.31 & yuan $/ \mathrm{m}^{2}$ & 51.15 \\
\hline Among & Output tax & 30.22 & 26.01 & yuan $/ \mathrm{m}^{2}$ & 4.21 \\
\cline { 2 - 6 } & Surcharge & 1.13 & 0.98 & yuan $/ \mathrm{m}^{2}$ & 0.15 \\
\hline
\end{tabular}

Third: installation engineering costs. Comparing the two projects, the analysis shows that the cost of

prefabricated buildings is not much different from the traditional cast-in-situ buildings. See Table 5 for details.

Table 5. Analysis of installation project costs

\begin{tabular}{|c|c|c|c|c|c|}
\hline Number & Project & $\begin{array}{c}\text { Traditional } \\
\text { building }\end{array}$ & $\begin{array}{c}\text { Prefabricated } \\
\text { building }\end{array}$ & Unit & Difference \\
\hline 1 & $\begin{array}{c}\text { Installation } \\
\text { work }\end{array}$ & 223.42 & 220.30 & yuan / $\mathrm{m}^{2}$ & 3.12 \\
\hline 1.1 & $\begin{array}{c}\text { Water supply } \\
\text { and drainage } \\
\text { part }\end{array}$ & 51.34 & 51.72 & yuan / $\mathrm{m}^{2}$ & -0.38 \\
\hline 1.2 & $\begin{array}{c}\text { Strong current } \\
\text { part }\end{array}$ & 80.1 & 76.12 & yuan / $\mathrm{m}^{2}$ & 3.98 \\
\hline 1.3 & $\begin{array}{c}\text { Weak current } \\
\text { part }\end{array}$ & 37.96 & 37.45 & yuan / $\mathrm{m}^{2}$ & 0.51 \\
\hline 1.4 & Fire department & 13.02 & 14.01 & yuan / $\mathrm{m}^{2}$ & 0.99 \\
\hline 1.5 & Elevator section & 41 & 41 & yuan / $\mathrm{m}^{2}$ & 0 \\
\hline
\end{tabular}

To sum up, the unilateral cost of prefabricated construction projects is 2017.51 yuan $/ \mathrm{m}^{2}$, while the traditional unilateral construction cost is 1748.24 yuan /

$\mathrm{m}^{2}$, the cost is increased by 269.27 yuan $/ \mathrm{m}^{2}$, and the increase rate is $15.40 \%$. See Table 6 for details.

Table6. Unilateral cost analysis

\begin{tabular}{|c|c|c|c|c|c|}
\hline Number & Project & $\begin{array}{c}\text { Traditional } \\
\text { building }\end{array}$ & $\begin{array}{c}\text { Prefabricated } \\
\text { building }\end{array}$ & Unit & Difference \\
\hline 1 & $\begin{array}{c}\text { building } \\
\text { structure }\end{array}$ & 1531.9 & 1208.36 & yuan / $\mathrm{m}^{2}$ & 323.54 \\
\hline 2 & $\begin{array}{c}\text { Decoration } \\
\text { works }\end{array}$ & 265.31 & 316.46 & yuan $/ \mathrm{m}^{2}$ & -51.15 \\
\hline 3 & $\begin{array}{c}\text { Installation } \\
\text { work }\end{array}$ & 220.30 & 223.42 & yuan $/ \mathrm{m}^{2}$ & -3.12 \\
\hline 4 & Unilateral cost & 2017.51 & 1748.24 & yuan $/ \mathrm{m}^{2}$ & 269.27 \\
\hline
\end{tabular}

5.4Analysis of the reasons for the cost difference between fabricated engineering and traditional cast-in-situ engineering

According to related theories and engineering practices, there are large differences in unilateral cost for the two different structural types. The main factors are the following: First, the structural system is different. The prefabricated structural system adopts reinforced concrete prefabricated partition wall panels; the traditional cast-in-situ shear wall structure uses partition hollow brick blocks. In terms of floor covering, the assembled structure uses PC laminated panels instead of the traditional cast-in-situ structure, which increases the thickness[12]. At the same time, prefabricated engineering requires gap grouting, which is not required for traditional building types. Second, in terms of material use, prefabricated structural systems use more than traditional cast-in-place systems, and they have high grades and strict requirements, such as partition boards instead of brick walls. Third, the construction technology and installation technology are immature, and the coordination between cast-in-place and hoisting is low, which also increases part of the cost.

\section{6 conclusion}

Prefabricated concrete structure has obvious advantages and is a new type of building model. Governments at all levels and administrative departments attach great importance to it, and their development has achieved certain results. Its construction cost is restricted by national policies, science and technology, and coordinated management. At present, prefabricated concrete structures are in the initial development stage. At present, it is in the initial stage of development, and 
there are still some shortcomings. Relevant departments of governments at all levels should give strong support and implement precise policies; all participating entities should actively explore and work hard to realize the industry's green management and sustainable development.

\section{Acknowledgments}

This research was financially supported by Jiangxi Provincial Department of Education's 2018 Scientific and Technological Research Project (Key Project) "Economic Analysis and Empirical Research on the Construction of Prefabricated Concrete Structure System" (Project Number: GJJ181383)

\section{References}

1. Yan Heping, Hu Youliang, Xiang Ming. Comparative Study of Costs between Prefabricated Construction Projects and Traditional Construction Projects [J] Construction Economy, 2017 (6)

2. Xu Dongmei, Ni Xingang, Xie Lan, Xu Zhengfei. Analysis of the construction cost of prefabricated buildings and its influencing factors [J] Shanxi Construction, 2018 (10)

3. Li Lihong, Geng Bohui, Qi Baoku, Lei Yunxia. Cost comparison and empirical research of prefabricated construction and cast-in-situ construction engineering [J] Architectural Economics, 2013 (9)
4. Wang Minghui. Research on cost control and countermeasures of construction engineering $[\mathrm{J}]$ Enterprise Reform and Management. 2016 (09)

5. Wan Lianjian. Research on Cost Control Approach of Prefabricated Building [J] Shanxi Architecture, 2015 (08).

6. He Jun. Analysis of key points of cost control of prefabricated buildings [J] Smart City, 2016 (11).

7. Wang Zixi. Research on the Cost Budget and Cost Control Approach of Green Building Project $[\mathrm{J}]$ Door and Window, 2016 (07).

8. Sun Lingzhi, Xu Shan, Wang Yanan. Research on Cost Management of Prefabricated Buildings under List Valuation Model [ J ] Building Economy, 2016 (02)

9. Gavilan R M, Bernold L E. Source evaluation of solid waste in building construction $[\mathrm{J}]$. Journal of Construction Engineering and Management, 1994, 120 (3): 536-552.

10. Li YZhang $\mathrm{X}$. Comparison and analysis of international construction waste management policies [C] Reston: ASCE, 2012: 1672-1681.

11. Zhu Baifeng. Research on greenness evaluation system of assembled monolithic buildings [D] Shenyang: Shenyang Jianzhu University, 2016.

12. Meng Nan. "Cost" will not hinder the development of prefabricated buildings $\quad[\mathrm{J}] \quad$ Architecture, 2016 (20): 19. 